\title{
ZnO-based Nano Biomimetic Smart Artificial Form Located on Lignocellulosic Surface with Hydrothermal Approach
}

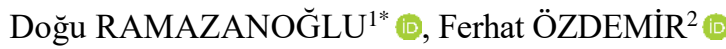

${ }^{1}$ Kahramanmaraş Sütçü İmam University, Material Science and Engineering, Kahramanmaraş, TURKEY

${ }^{2}$ Kahramanmaraş Sütçü İmam University, Forest Industry Engineering, Kahramanmaraş, TURKEY

*Corresponding Author: doguramazanoglu@ hotmail.com

\section{Abstract}

Aim of study: In this study, a ZnO-based smart artificial nano biomimetic form is created on the wooden surface with the hydrothermal approach to increase the resistance of the wood against moisture and water and provide a more hygienic surface.

Material and methods: Zinc borate, Zinc oxide, Sodium hydroxide and Hydrochloric acid were hydrothermally applied to the massive surface to synthesize the $\mathrm{ZnO}$-based nano biomimetic structure on the lignocellulosic surface. The hydrophobization step was achieved using $1 \mathrm{H}, 1 \mathrm{H}, 2 \mathrm{H}, 2 \mathrm{H}-$ Perfluorodecyltriethoxysilane. In the characterization step; XRD, EDX, SEM and TGA analyzes were done. WCA analysis was performed to determine the hydrophobicity feature.

Main results: $\mathrm{ZnO}$-based nano biomimetic smart surface form with photo catalyst feature created on the wooden surface has provided a water contact angle of $\theta \gamma 145^{\circ}$.

Highlights: Synthesized ZnO-based nano biomimetic smart surface form has given the wooden material a hydrophobic structure. Thanks to the new feature gained by functionalizing the lignocellulosic surface, it is predicted to be preferred in all areas where hygiene is desired.

Keywords: Smart, Nano, Biomimetic

\section{Hidrotermal Yaklaşım ile Lignoselülozik Yüzeyde \\ Konumlandırılan ZnO Esaslı Nano Biyomimetik Akılı Yapay Form}

Öz

Çalışmanın amacı: $\mathrm{Bu}$ çalışmada, hidrotermal yaklaşımla ahşap yüzeyde $\mathrm{ZnO}$ esaslı akıllı yapay nano biyomimetik form oluşturularak ahşabın neme ve suya karşı olan direncinin artırarak daha hijyenik bir yüzeye sahip olmasını sağlamaktır.

Materyal ve yöntem: $\mathrm{ZnO}$ esaslı nano biyomimetik yapının lignoselülozik yüzeyde sentezlenmesi için Çinko borat, Çinko oksit, Sodyum hidroksit ve Hidroklorik asit masif yüzeye hidrotermal olarak uygulanmıştır. Hidrofobizasyon aşamasında $1 \mathrm{H}, 1 \mathrm{H}, 2 \mathrm{H}, 2 \mathrm{H}-$ Perfluorodecyltriethoxysilan kullanılarak sağlanmıştır. In the characterization step; XRD, SEM, EDX and TGA analyzes were performed. WCA analysis was performed to determine the hydrophobicity property.

Temel sonuçlar: Ahşap yüzeyde oluşturulan foto katalizör özellikli $\mathrm{ZnO}$ esaslı nano biyomimetik akıllı yüzey formu $\theta \gamma 145^{\circ}$ lik su temas açısı sağlanmıştır.

Araştırma vurguları: Sentezlenen $\mathrm{ZnO}$ esaslı nano biyomimetik akıllı yüzey formu ahşap malzemeye hidrofobik bir yapı kazandırmıştır. Lignoselülozik yüzeyin fonksiyonlandılmasıyla kazandırılan yeni özellik sayesinde hijyen istenen her türlü alanda tercih sebebi olması öngörülmektedir.

Anahtar kelimeler: Akıllı, Nano, Biyomimetik 


\section{Introduction}

Wooden materials are widely used in daily life (Hsieh et al., 2011; Toivonen, 2012). Insects, microorganisms (Faix et al., 1991) sunlight (Evans et al., 2002) moisture (Evans et al., 2002; Hameury, 2005) and low combustion resistance agents reduce the service life of wood materials especially in outdoor areas preservation of objects and structures of historical value made of wood is very important in this respect. The most important factor for the protection of wood materials has been defined as hydrophobic functioning or conversion of hydrophilic structures (Toivonen, 2012).

According to some textile reports the fabric producing with nano-zinc coating cotton provide good strength, well air permeability and UV-absorption feature to final product (Yadav et al., 2006). Moreover, Zinc oxide $(\mathrm{ZnO})$ as catalyst could even improve to enhance the flame-retardant action of fabric (Well \& Levchik 2004). This kind of surface formations are available in studies in which wooden surface is made with Titanium oxide $\left(\mathrm{TiO}_{2}\right)$. Subsequently, a nanoscale hydrophobic structure was obtained by functioning water with silane or fluorinecontaining polymers of this $\mathrm{TiO}_{2}$-formed surface (Guan, 2005; Feng et al., 2005).

Biomimetics is a term coined by Otto Schmitt in the 1950s for the transfer of ideas and simulations from biology to technology (Vincent et al., 2006). Smart materials are defined as materials that respond to a predetermined external stimulus in a controlled manner (Murphy \& Wudl 2010; Özdemir et al., 2018). These materials change shape, mechanical hardness/flexibility, opacity and porosity, etc. against changing external stimuli. They are materials that can respond by changing their properties. Many living things living in the ecosystem can change the external surface properties of their bodies in order to adapt to the environment they live in. These surfaces are of great interest in multiple disciplines due to their potential to be applied in various fields (Bixler et al., 2014).

Later in their study, they also observed that the air could be trapped under a drop of water in the air, consistent with the Cassie-Baxter equation. These findings revealed that lotus leaf-like high water-repellent super hydrophobic surfaces can be produced using micro/nano hierarchical structures coated with low surface energy materials. Inspired by lotus leaves, wet chemical etching (Kim et al., 2009), electrochemical reaction (He \& Wang 2011; Thomas et al., 2015), lithography (Kavalenka et al., 2014), electrodynamics (Sarkar et al., 2011), sol-gel methods (Mahadik et al., 2012; Latthe et al., 2014). Layer-by-layer deposition (Buck et al., 2010) and exposure to plasma methods have been developed to produce these surfaces (Salapare et al., 2013; Kessler et al., 2012).

In this study, it is aimed to improve the waterproof properties of wooden materials, which is the weakest aspect. For this purpose, $\mathrm{ZnO}$ nanoparticles were used to create a biomimetic structure inspired by the morphological properties of the lotus leaf in wood, and the attachment of $\mathrm{ZnO}$ nanoparticles to the lignocellulosic surface was achieved by the hydrothermal method. Then, in a second hydrothermal process, hydrophobization was performed on the lignocellulosic surface using trimethoxysilane (heptadecafloro-1,1,2,2-tetradecyl)

designated FAS-17. By covering the $\mathrm{ZnO}$ nanoparticles of FAS-17, a smart biomimetic tissue with a water contact angle of $145^{\circ}$ was created on the lignocellulosic surface.

\section{Material and Methods \\ Materials}

Beech wood species was purchased from commercial market in Kahramanmaras, Turkey. Zinc borate $\left(2 \mathrm{ZnO} \cdot 3 \mathrm{~B}_{2} \mathrm{O}_{3} \cdot 3.5 \mathrm{H}_{2} \mathrm{O}\right)$ were supplied from Etimine in Luxembourg. Zinc oxide $(\mathrm{ZnO})$, Ethyl alcohol $(\mathrm{EtOH})$, Methanol $\left(\mathrm{CH}_{3} \mathrm{OH}\right)$, Hydrochloric acid ( $\left.\mathrm{HCI}\right)$ and Sodium hydroxide $(\mathrm{NaOH})$ were provided by TEKKIM in Istanbul Turkey. Trimethoxysilane (heptadecafluoro-1,1,2,2tetradecyl) $\left(\mathrm{CF}_{3}\left(\mathrm{CF}_{2}\right)_{7} \quad \mathrm{CH}_{2} \mathrm{CH}_{2} \mathrm{Si} \quad\left(\mathrm{OCH}_{3}\right)_{3}\right.$ named as FAS-17 was purchased from SigmaAldrich.

\section{Methods}

For thermogravimetric analysis, EXSTAR TG/DTA 6300 brand, SEM images and EDX spectra were made with Zeiss Eva 50 ED brand and XRD spectra were made with Rigaku Rint 2000 brand device in 
KSÜ/ÜSKIM. Water contact angle measurements were carried out with KSV Cam101 Scientific Instrument (Helsinki, Finland) brand devices located in the forest faculty of Istanbul University where been used.

\section{Preparation of Wood Specimens}

The wood samples, which were set to 2 $\mathrm{mm}$ (radial) $\mathrm{x} 10 \mathrm{~mm}$ (tangent) $\mathrm{x} 15 \mathrm{~mm} \times$ (longitudinal) in the specified dimensions, were washed with pure water in ultrasonic bath for 30 minutes and then dried in the oven for 48 hours at $105^{\circ} \mathrm{C}$ (Figure 1)

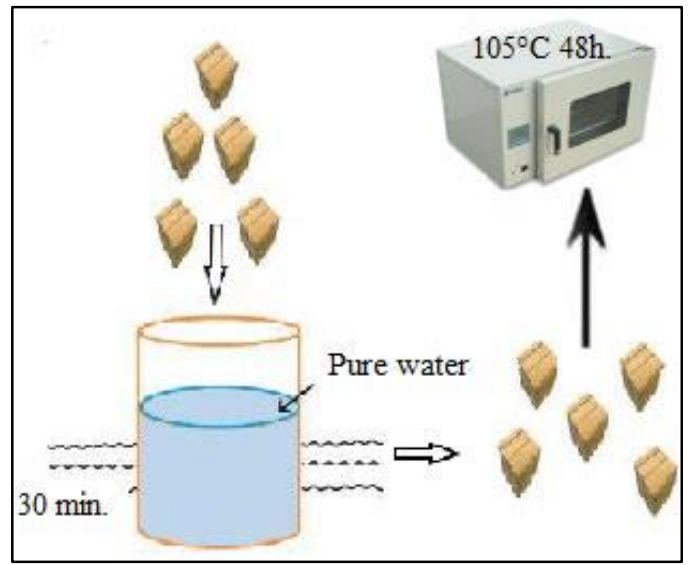

Figure 1. Schematic representation of sample preparation.

\section{Functioning the Wood Surface with $\mathrm{ZnO}$}

In order to synthesize the $\mathrm{ZnO}$ nanoparticles positioned on the wooden surface with a hydrothermal approach, firstly $1.2 \mathrm{M}$ Zinc borate $\left(2 \mathrm{ZnO} \cdot 3 \mathrm{~B}_{2} \mathrm{O}_{3} \cdot 3.5 \mathrm{H}_{2} \mathrm{O}\right)$ and $0.4 \mathrm{M}$ Zinc oxide $(\mathrm{ZnO}) 50 \mathrm{ml}$ reaction solution was prepared (Figure 2).

Then, $0.3 \mathrm{M}$ hydrochloric acid solution was gradually added to the prepared solution until the $\mathrm{pH}$ value was approximately 3 . After, this reaction solution, whose $\mathrm{pH}$ value was adjusted to 3, was transferred to the teflon vessel of the hydrothermal reactor. Wood particles exposed to the sample preparation process were added to the reaction solution, and the hydrothermal reactor, which was tightly closed, was left to cool at room temperature after standing for 5 hours at 90 ${ }^{\circ} \mathrm{C}$, as shown in (Figure 2) respectively. Finally, the prepared samples were taken from their solutions and the samples washed 3 times in an ultrasonic bath with pure water to remove excess chemicals that do not cling to their surfaces were left to dry for 24 hours at $60{ }^{\circ} \mathrm{C}$ (Gao et al., 2015a).

\section{Hydrophobization Process of Wood Surface Treated with $\mathrm{ZnO}$}

Wood samples treated with precursor solutions containing $\mathrm{ZnO}$ were functionalized with fluoroalkyl silane (FAS-17) at this stage. Hydrolyzed at room temperature by adding 60 $\mathrm{ml}$ of pure water to a $20 \mathrm{ml}$ methyl alcohol solution containing $0.20 \mathrm{ml}$ of FAS-17. Then this reaction solution, set at $20 \mathrm{ml}$, was transferred to $100 \mathrm{ml}$ reactor. The sealed reactor was heat treated at $80{ }^{\circ} \mathrm{C}$ for 5 hours (Figure 3). At the end of the heat treatment, after the reactor cooled at room conditions, the samples removed were left to dry at room temperature by washing with ethyl alcohol to remove excess chemicals that did not participate in the reaction. It was left to dry thoroughly at $60^{\circ} \mathrm{C}$ for 24 hours to completely remove the ethyl alcohol from sample (Figure $3)$. The desired hydrophobic wood surface was obtained (Gao et al., 2015b).

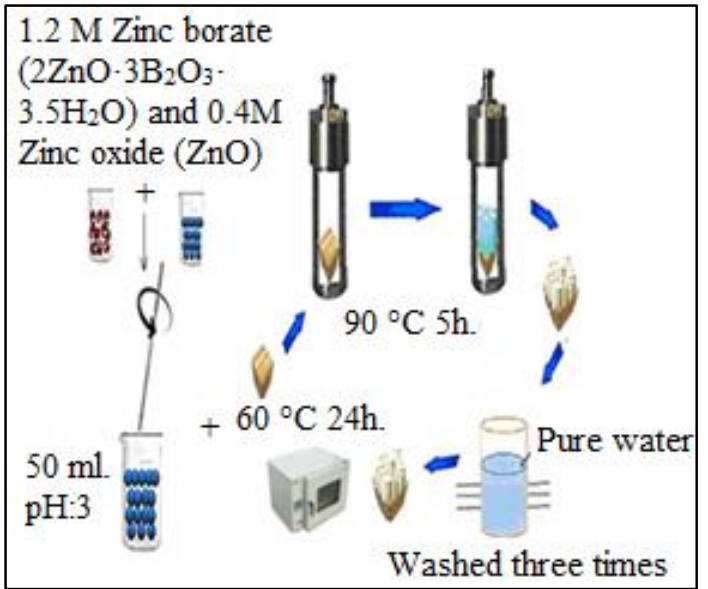

Figure 2. Schematic representation of $\mathrm{ZnO}$ film coating of wood surface by hydrothermal method.

\section{Hydrophobization Process of Wood Surface Treated with $\mathrm{ZnO}$}

Wood samples treated with precursor solutions containing $\mathrm{ZnO}$ were functionalized with fluoroalkyl silane (FAS-17) at this stage. Hydrolyzed at room temperature by adding 60 $\mathrm{ml}$ of pure water to a $20 \mathrm{ml}$ methyl alcohol solution containing $0.20 \mathrm{ml}$ of FAS-17. Then this reaction solution, set at $20 \mathrm{ml}$, was 
transferred to $100 \mathrm{ml}$ reactor. The sealed reactor was heat treated at $80{ }^{\circ} \mathrm{C}$ for 5 hours (Figure 3). At the end of the heat treatment, after the reactor cooled at room conditions, the samples removed were left to dry at room temperature by washing with ethyl alcohol to remove excess chemicals that did not participate in the reaction. It was left to dry thoroughly at $60^{\circ} \mathrm{C}$ for 24 hours to completely remove the ethyl alcohol from sample (Figure $3)$. The desired hydrophobic wood surface was obtained (Gao et al., 2015b).

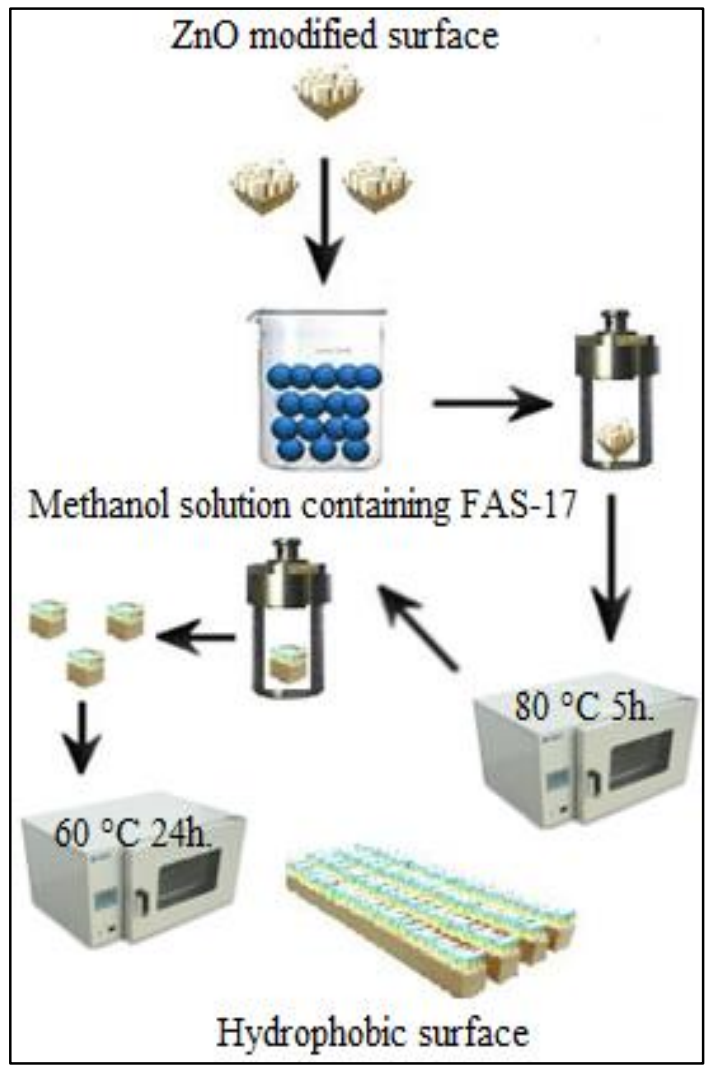

Figure 3. Schematic representation of wood surface hydrophobization obtained using FAS-17.

\section{Results and Discussion}

Analysis of XRD Spectrometry

XRD spectra of massive wood exposed to hydrothermal process with reactor solution prepared using $1.2 \mathrm{M}$ Zinc borate $\left(2 \mathrm{ZnO} \cdot 3 \mathrm{~B}_{2} \mathrm{O}_{3} \cdot 3.5 \mathrm{H}_{2} \mathrm{O}\right)$ and $0.4 \mathrm{M}$ Zinc oxide $(\mathrm{ZnO})$ are shown in Figure 4.

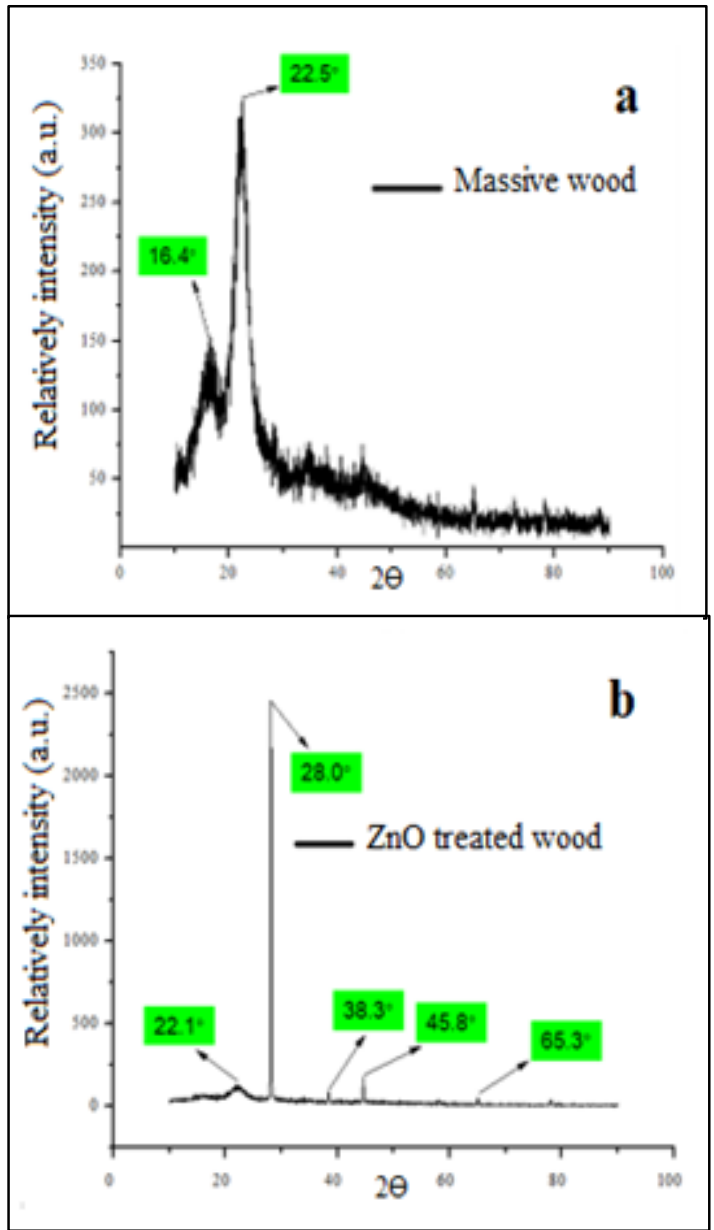

Figure 4. XRD spectrum of (a) solid wood (b) $\mathrm{ZnO}$ interfered wood

In Figure 4, the peaks appearing in the spectrum of solid wood at $16.4^{\circ}$ and $22.5^{\circ}$ degrees are cellulose peaks in the characteristic wood structure (Ramazanoğlu $\&$ Özdemir, 2020). The diffraction peaks seen at $22.1^{\circ} 28.0^{\circ} 38.3^{\circ} 45.8^{\circ}$ and $65.3^{\circ}$ in the XRD spectrum of the wood sample treated with $\mathrm{ZnO}$ show that $\mathrm{ZnO}$ crystallization occurred on the lignocellulosic surface (Aad et al., 2013).

\section{Thermogravimetric Analysis}

The TG and DTG plots of the sample coated with FAS-17 after reacting with the reactor solution prepared by mixing zinc borate $\left(2 \mathrm{ZnO} \cdot 3 \mathrm{~B}_{2} \mathrm{O}_{3} \cdot 3.5 \mathrm{H}_{2} \mathrm{O}\right)$ and Zinc oxide $(\mathrm{ZnO})$ are as in Figure 5. 

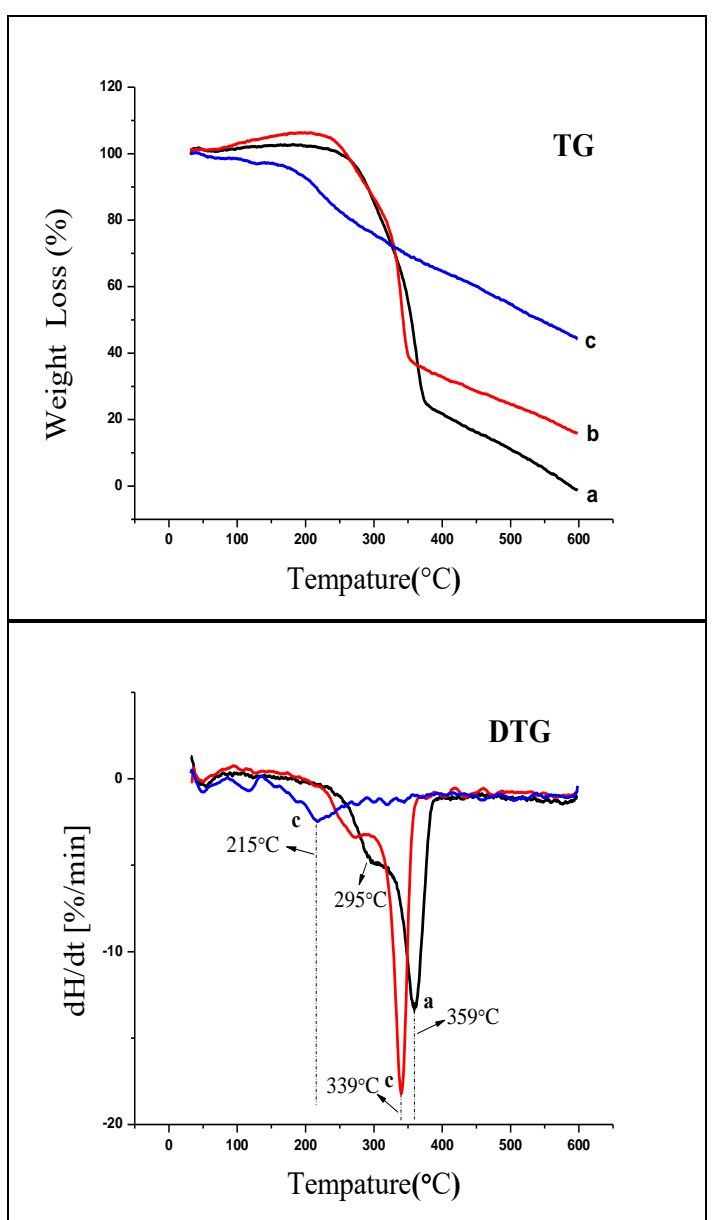

Figure 5. Thermal analysis (TG/DTG) profile (a) solid wood; (b) $\mathrm{ZnO}$ interfered wood (c) ZnO-treated wood hydrophobization with FAS-17.

TG curves are partially similar up to 100 ${ }^{\circ} \mathrm{C}$ due to the removal of water in the structure (Zhou et al., 2011). The shoulder at $295{ }^{\circ} \mathrm{C}$ (Figure 5a) on the DTG-a graph results from depolymerization of hemicellulose and the second shoulder at $359{ }^{\circ} \mathrm{C}$ due to the degradation of cellulose (Ouajai \& Shanks, 2005). In the DTA curve (Figure 5.), at least $339{ }^{\circ} \mathrm{C}$ for the $\mathrm{ZnO}$ treated surface corresponding to the weight losses shown in the TG curve (Figure $5 \mathrm{~b}$ and c); Strong and sharp endothermic peaks occurred at $215^{\circ} \mathrm{C}$ for the surface treated with ZnO@FAS-17. When the weight amounts lost in TG curves are compared, it is observed that the mass lost by the $\mathrm{ZnO}$ and $\mathrm{ZnO@FAS-17} \mathrm{samples} \mathrm{is}$ lower than the massive sample. When the lost weight amounts in TG curves are compared, it is observed that the mass lost by the Wood$\mathrm{ZnO}$ and Wood-ZnO@FAS-17 samples is lower than the massive one. This is due to the fact that FAS-17 depolymerization acts as a barrier and effectively protects wood. The $\mathrm{ZnO}$ particles surrounding the wood surface act like a catalyst and accelerate the pyrolysis time, creating a protective layer on the wood Calculated weight losses during the whole process were approximately $98.7 \%$ for original wood, $84.1 \%$ for $\mathrm{ZnO}$ treated wood and 55.5\% for ZnO@ FAS-17 treated wood.

\section{Water Contact Angle}

Water contact angles of the original wood (a), the surface where the $\mathrm{ZnO}$ nanoparticles are positioned by hydrothermal approach (b), the surface FAS-17 hydrophobized (c), and (d) the surface samples that are hydrophobed with the FAS-17 after the hydrothermal positioning of the $\mathrm{ZnO}$ particles were given in Figure 6.

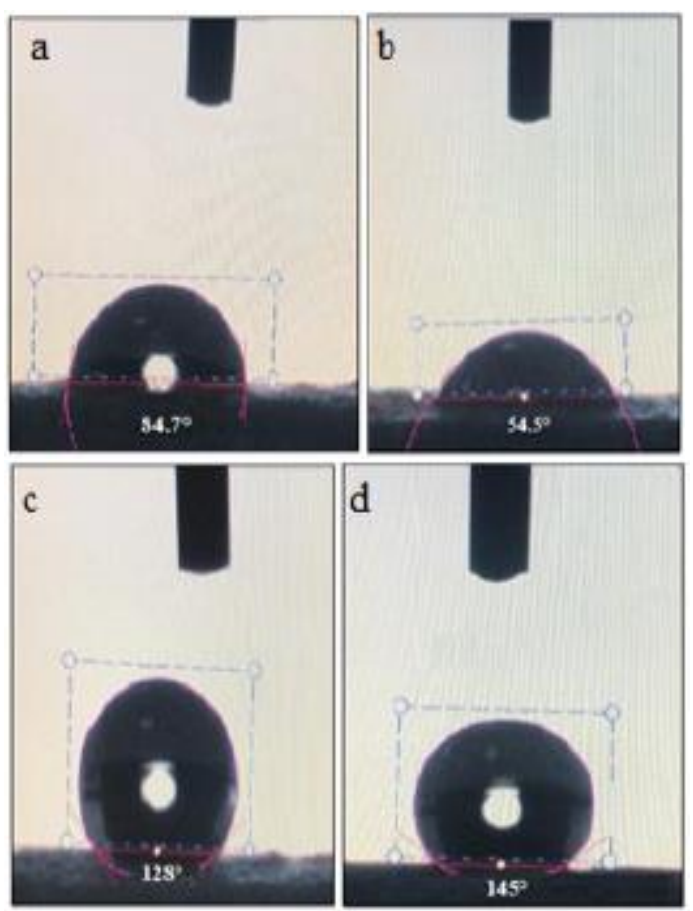

Figure 6. untreated wood (a), $\mathrm{ZnO}$ treated wood (b), FAS-17 treated wood (c) and (d) $\mathrm{ZnO}$ and FAS-17 treated wood.

While the water contact angle of massive wood was $84.7^{\circ}$ (Figure 6a), after the hydrothermal location of $\mathrm{ZnO}$ nano particles, it decreased by $35.6 \%$ and became $54.5^{\circ}$ (Figure 6b) (Gan et al., 2015). In this study, the rough surface water contact angle was found to be $\theta \gamma 128^{\circ}$ as a result of its 
structuring in the sample taken into hydrophobization process with FAS-17 (Figure 6c). However, the fluoroalkyl silane (FAS-17) applied to the sample coated by $\mathrm{ZnO}$ nanostructures as a result of lowtemperature hydrothermal application increased the water contact angle to $\theta \gamma 145^{\circ}$ with an increase amount of $13.2 \%$ (Figure 6d).

\section{SEM \& EDX Analysis}

The untreated sample (a); SEM photographs and EDX spectra of the surfaces covered with $\mathrm{ZnO}$ nanoparticles (b) and (c) after the $\mathrm{ZnO}$ intervention, which are hydrophobized with FAS-17 are given in Figure 7.

In the EDX spectrum of the massive sample (Figure 7a), it is seen in the peak of the gold coating made to provide surface conductivity, as well as oxygen and carbon peaks arising from the cellulosic structure. Zinc peak is seen in the EDX spectrum (Figure $7 \mathrm{~b}$ ) of the surface covered with $\mathrm{ZnO}$ nano particles and the presence of non-severe $\mathrm{Zn}$ and F peaks (Figure 7c.) in the last stage hydrophobization (Gao et al., 2015a). In addition, the SEM photo in Figure $7 \mathrm{~b}$ shows the $\mathrm{ZnO}$ nano particles (Li et al., 2015) located on the wooden surface. In Figure 7c, it is seen that $\mathrm{ZnO}$ nano particles are covered by wax crystalloids after hydrophobization with FAS17. Such biomimetic formations on the lignocellulosic surface are indispensable for water repellency (Xia et al., 2012; Li, et al., 2015; Lu \& Li, 2015).
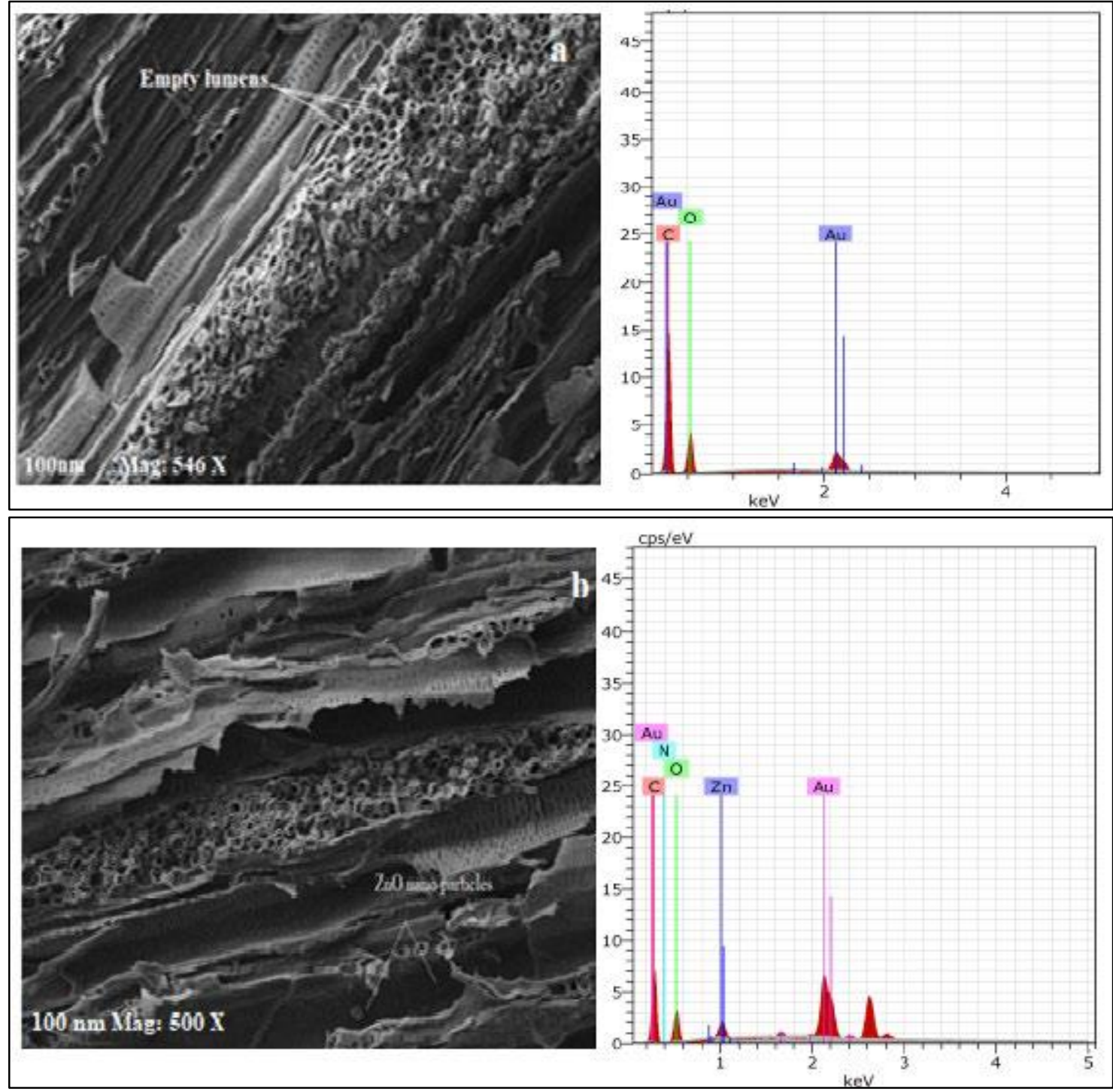


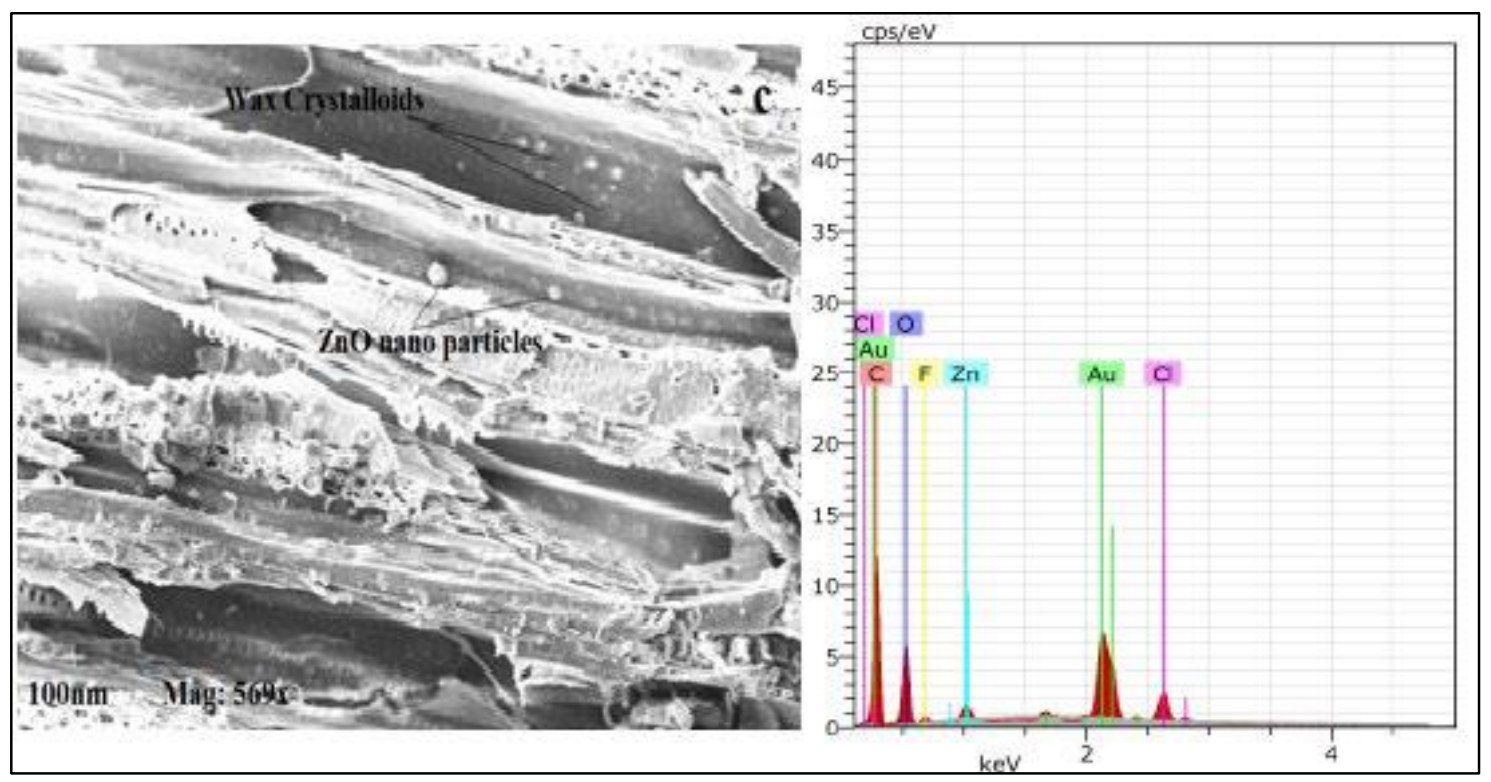

Figure 7. SEM images and EDX spectrum of (a) Massive wood, (b) Massive-ZnO and (c) Massive-ZnO@FAS-17.

\section{Conclusions}

In this study, it is aimed to strengthen the resistance of the wood, which is a common use area in living spaces, to fire and humidity and to extend its lifetime. In line with this goal, it is aimed to create a $\mathrm{ZnO}$ based nano biomimetic structure on the wooden surface. In the characterization studies carried out that In X-ray diffraction (XRD) spectrum; The diffraction peaks appeared at $22.1^{\circ} 28.0^{\circ}$ $38.3^{\circ} 45.8^{\circ}$ and $65.3^{\circ}$ shows that $\mathrm{ZnO}$ nano particles were crystallized on wood surface. SEM photographs shows $\mathrm{ZnO}$ nano particles and wax crystalloids structure of FAS-17 after hydrophobisation spectrum $\mathrm{Zn}$ and $\mathrm{F}$ peaks have been appearing after all functionalization. After the crystallization of $\mathrm{ZnO}$ nanoparticles on the surface, reduction in water contact angle, increase after intervention with FAS-17 and TGA analysis; proves that $\mathrm{ZnO}$ based smart nano biomimetic form has been successfully created on the wooden surface.

\section{Ethics Committee Approval N/A}

\section{Peer-review}

Externally peer-reviewed.

\section{Author Contributions}

Conceptualization:

Investigation: D.R.; Material and Methodology: D.R., F.Ö.; Supervision: F.Ö. Visualization: D.R.; Writing-Original Draft: D.R.; Writing-review\&Editing: D.R. All authors have read and agreed to the published version of manuscript.

\section{Conflict of Interest}

The authors have no conflicts of interest to declare.

\section{Funding}

This study has been supported within the scope of project numbered 2018/3-20 D. by Kahramanmaras Sutcu Imam University, Scientific Research Projects Coordination Department.

\section{References}

Aad, R., Simic, V., Cunff, L.L., Rocha, L., Sallet, V., Sartel, C., Lusson, A., Couteaua, C., \& Lerondel G. (2013). $\mathrm{ZnO}$ nanowires as effective luminescent sensing materials for nitroaromatic. Derivatives Nanoscale, 5, 91769180.

Bixler, G. D., Theiss, A., Bhushan, B. \& Lee, S. C. (2014). Anti-fouling properties of micro structured surfaces bio-inspired by rice leaves and butterfly wings. Journal of Colloid and Interface Science, 419, 114-133. 
Buck, M. E., Schwartz, S. C. \& Lynn, D. M. (2010). Superhydrophobic Thin Films Fabricated by Reactive Layer-by-Layer Assembly of Azlactone-Functionalized Polymers. Chemistry of Materials, 22(23), 6319-6327.

Evans, P. D., Owen, N. L., Schmid, S. \& Webster R. D. (2002). Weathering and photo stability of benzylated wood. Polymer Degradation and Stability, 76(2), 291-303.

Faix, O., Bremer, J., Schmidt, O. \& Tatjana, S. J. (1991). Monitoring of chemical changes in white-rot degraded beech wood by pyrolysisgas chromatography and Fourier-transform infrared spectroscopy. Journal of Analytical and Applied Pyrolysis, 21(1-2), 147-162.

Feng, X., Zhai, J., \& Jiang L. (2005). The Fabrication and Switchable Super hydrophobicity of $\mathrm{TiO}_{2}$ Nanorod Films. Ange Wanted Chemie, 44(32), 5115-5118.

Gan, W., Gao, L., Sun, Q., Jin, C., Lu, Y., \& Li, J. (2015). Multifunctional wood materials with magnetic, superhydrophobic and antiultraviolet properties. Applied Surface Science, 332, 565-572.

Gao, L., Lu, Y., Zhan, X. \& Sun, Q. (2015a). A robust, anti-acid, and high-temperature humidity-resistant superhydrophobic surface of Wood based on a modified $\mathrm{TiO}_{2}$ film by fluoroalkyl silane. Surface and Coatings Technology, 262, 33-39.

Gao, L., Xiao, S., Gan, W., Zhan X. \& Li, J., (2015b). Durable superamphiphobic wood surfaces from $\mathrm{Cu}_{2} \mathrm{O}$ film modified with fluorinated alkyl silane. Royal Society of Chemistry, 5, 98203-98208.

Guan, K. S. (2005). Relationship between photocatalytic activity, hydrophilicity and self-cleaning effect of $\mathrm{TiO}_{2} / \mathrm{SiO}_{2}$ films. Surface and Coatings Technology, 191, 155160.

Hameury, S. (2005). Moisture buffering capacity of heavy timber structures directly exposed to an indoor climate: a numerical study. Building and Environment, 40(10), 1400-1412.

He, G. \& Wang, K. (2011). The super hydrophobicity of $\mathrm{ZnO}$ nanorods fabricated by electrochemical deposition method. Applied Surface Science, 257(15), 6590-6594.

Hsieh, C. T., Chang, B. S. \& Lin, J. Y. (2011). Improvement of water and oil repellency on wood substrates by using fluorinated silica nanocoating, Applied Surface Science, 257(18), 7997-8002.

Kavalenka, M. N., Hopf, A., Schneider, M., Worgull, M. \& Hölscher, H. (2014). Woodbased microhaired superhydrophobic and underwater superoleophobic surfaces for oil/water separation, RSC Advances, 4(59), 31079-31083.

Kessler, F., Kühn, S., Radtke, C. \& Weibel, D. E. (2012). Controlling the surface wettability of poly(sulfone) films by UV-assisted treatment: benefits in relation to plasma treatment, Polymer International, 62(2), 310-318.

Kim, T., Tahk, D. \& Lee, H.H. (2009). Wettability-Controllable Super Water- and Moderately Oil-Repellent Surface Fabricated by Wet Chemical Etching. Langmuir, 25(11), 6576-6579.

Latthe, S. S., Terashima, C., Nakata, K., Sakai, M. \& Fujishima, A. (2014). Development of solgel processed semi-transparent and selfcleaning superhydrophobic coatings. Journal of Materials Chemistry A, 2(15), 5548-5553.

Lu, B. \& Li, N. (2015). Versatile aluminum alloy surface with various wettability. Applied Surface Science, 326, 168-173.

Li, J., Sun, Q., Jin, C. \& Li, J. (2015). Comprehensive studies of the hydrothermal growth of $\mathrm{ZnO}$ nanocrystals on the surface of bamboo. Ceramics International, 41(1), 921929.

Mahadik, S., Mahadik, D. B., Kavale, M. S., Parale, V. G., Wagh, P. B., Barshilia, H., Gupta, S., Hegde, N. D. \& Rao, A. V. (2012). Thermally stable and transparent superhydrophobic sol-gel coatings by spray method. Journal of Sol-Gel Science and Technology, 63(3), 580-586.

Murphy, E. B. \& Wudl, F. (2010). The world of smart healable materials. Progress in Polymer Science, 35(1-2), 223-251.

Ouajai, S. \& Shanks, R. A. (2005). Composition, structure and thermal degradation of hemp cellulose after chemical treatments. Polymer Degradation and Stability, 89(2), 327-335.

Özdemir, F., Ramazanoğlu. D. \& Tutuş, A. (2018). Akıllı malzemeler için biyomimetik yüzey tasarımlar1. Journal of Bartin Faculty of Forestry, 20(3), 1-1.

Ramazanoğlu, D. \& Özdemir, F. (2020). Hidrotermal yaklaşımın lignoselülozik yüzeydeki akıllı nano biyomimetik yansıması, Turkish Journal of Forestry, 21(3), 324-331.

Sarkar, M. K., Bal, K., He, F. \& Fan, J. (2011). Design of an outstanding super-hydrophobic surface by electro-spinning. Applied Surface Science, 257(15), 7003-7009.

Salapare, H. S., Guittard, F., Noblin, X., Taffin de Givenchy, E., Celestini, F. \& Ramos, H. J. (2013). Stability of the hydrophilic and superhydrophobic properties of oxygen plasma-treated poly (tetrafluoroethylene) surfaces. Journal of Colloid and Interface Science, 396, 287-292. 
Toivonen, R. M. (2012). Product quality and value from consumer perspective an application to wooden products. Journal of EconomicsSpringer, 18(2), 157-173.

Thomas, Y. R. J., Benayad, A., Schroder, M., Morin, A. \& Pauchet, J. (2015). New Method for Super Hydrophobic Treatment of Gas Diffusion Layers for Proton Exchange Membrane Fuel Cells Using Electrochemical Reduction of Diazonium Salts. ACS Applied Materials \& Interfaces, 7(27), 15068-15077.

Vincent, J. F., Bogatyreva, O. A., Bogatyrev, N. R., Bowyer, A. \& Pahl, A. K. (2006). Biomimetics: its practice and theory. Journal of The Royal Society Interface, 3(9), 471-482.

Well, E.D. \& Levchik, S. (2004). Current practice and recent commercial developments in flame retardancy of polyamides. Journal of Fire Sciences, 22(3), 251-264.

Xia, T., Li, N., Wu, Y. \& Liu, L. (2012). Patterned superhydrophobic surface based on Pd-based metallic glass. Applied Physics Letters, 101(8), 081601.

Yadav, A., Prasad, V., Kathe, A.A., Raj, S., Yadav, D., Sundar Moorthy, C. \& Vigneswaran, N. (2006). Functional finishing in cotton fabrics using zinc oxide nanoparticles. Bulletin of Materials Science, 29(6), 641-645.

Zhou, W., Sun, F., Pan, K., Tian, G., Jiang, B., Ren, Z., Tian, C. \& Fu, H. (2011). WellOrdered Large-Pore Mesoporous Anatase $\mathrm{TiO}_{2}$ with Remarkably High Thermal Stability and Improved Crystallinity: Preparation, Characterization, and Photocatalytic Performance. Advanced Functional Materials, 21(10), 1922-1930. 